\title{
Genre Approach to English Writing in Chinese College Teaching
}

\author{
XU Xiao-fei \\ Nanhu College, Jiaxing University, Jiaxing, China
}

\begin{abstract}
Writing has generally been considered as one of the most difficult tasks in second language learning. Therefore, most of the studies and public ones show that genre approach facilitates English writing. In this essay, the author will give a general introduction to genre approach to writing, analyze both the perspective of linguistic and that of educational efficiency, and then focus on genre approach, which not only improves the writing proficiency of Chinese college students, but also prepares them for the writing for specific purposes that will be especially useful for them after they graduate.
\end{abstract}

Keywords: Chinese college teaching, genre approach, English writing

\section{Introduction}

In the recent decades, scholars and teachers have been trying to find effective ways to teach writing, among which product and process approaches have been in the dominant place for a long time in China. Later, they have been found to be ineffective in certain aspects. Therefore, teaching writing remains a demanding task for EFL (English as a Foreign Language) teachers. Fortunately, genre-based approach brings us a useful and practical way to organize writing in the classroom (QIN, 2000). As for Chinese college students, they are likely to face many new writing situations that ask them to write in a specific and appropriate way for a specific discourse community. Writing in new genres can be difficult when you do not know what is expected, but analyzing the genre can provide them with a useful strategy for learning more about the expectations.

\section{Major Problems of Teaching Writing and Learning in China}

As many language teachers have noted, acquiring the writing skill seems to be more laborious than acquiring the rest of skills for L2 (second language) language learners (QIN, 2000). Hyland (2003) claims the difficulties in writing may come from the fact that students have to write different types of texts after being taught linguistic features. However, it is even harder for students to write a specific genre cohesively based on conventions (Flowerdew, 2000). Admittedly, the original purpose of teaching a foreign language is to communicate efficiently. In the audio-lingual era, the intuitive perception of communication was to cultivate people's ability of speaking and listening. However, the fact is that we cannot teach English without touching the area of writing. Since writing is very difficult to teach, teachers use every means to try different ways to improve the students' writing skills. The process approach and product approach which have dominated the Chinese writing classrooms for years (QIN, 2000), have proved to be insufficient in teaching writing to the

XU Xiao-fei, assistant lecturer, master, Department of Humanities, Nanhu College, Jiaxing University. 
college students because they may meet a lot different genres in their studies and in their future work. Recently, an approach based on genre theories has attracted more and more attention in this field.

Unlike reading or listening, writing requires views and opinions of the writer. Many college undergraduates find it easier to read than to write. After years of schooling, they have received good training of writing in their mother tongue, Chinese. But as for writing in English, they are either not well trained or not trained at all in their high school English classes. To them, the biggest problem is that since they are not skilled in using language materials and they have not enough language materials input, they cannot express their ideas fluently through writing. Therefore, teaching writing skills' in college settings to undergraduates are very urgent issues. Because the students have not had adequate experience in writing in English, especially writing the genres required college education and in the future work, and because their English proficiencies seem not strong enough for them to organize the ideas into an essay in a logical way, and also their mother tongue cannot be avoided, interfering with the writing process they undertake from time to time. Therefore, it becomes important to make decisions about what and how to teach becomes problematic. What is more, they are not familiar with the way of thinking in English. Their compositions are usually rather awkward to readers. Although they have already had a lot of grammatical knowledge, it is inevitable for quite a few of them to make some grammar mistakes here and there in composing their essays. Thus, teachers in this field are trying hard to help the students in all the respects.

\section{Pedagogical Approaches to English Writing}

Genre can be generally interpreted as different types of literature. Swales (1990) regards a genre as "a class of communicative events, the members of which share some set of communicative purposes" (p. 58). Tribble (1996) also agrees with his idea that there are certain conventions which are generally associated with communication purpose. Moreover, Dudley-Evans and St. John (1998) conclude that it is the study of regularities in the internal structure of different types of articles. The genre approach is built based on the theory that learning can be accessed by imitation and explicit instruction (Badger \& White, 2000). In the genre-based classroom activity, students are provided with models of the target genre. The teacher then gives instructions to them on analyzing samples and finding out the similarities of key features in the same genre. The students will consciously imitate the framework concluded from the model and finally produce a text independently. Furthermore, there have emerged three schools which do some research in genre analysis and its application: (1) English for Specific Purposes; (2) the North American New Rhetoric studies; and (3) Australian systemic functional linguistics (Hyon, 1996; Johns, 2002; Hyland, 2008). One of the genre "schools" is the genre-based approach in the field of ESP (English for Specific Purposes) which was put forward by Hyon (1996). But recently, genre approaches have drawn more and more attention in EFL writing classroom. This approach analyses the particular conventions, grammatical as well as organizational, of specific types of texts which students need to be able to produce rapidly for English specific purpose (Swales \& Feak, 1994; Hyon, 1996; Johns, 2002; Hyland, 2008).

As mentioned above and taking process approach and product approach into consideration, I support the genre approach employed to facilitate the teaching of writing because it combines with the relative merits of product and process approach, namely requiring students to comprehend and take into account the purpose, 
audience, and context of the written work; enables students to use language individually based on the framework of a given genre in social context. Badger and White (2000) assert the process approach mainly focuses on developing students' linguistic skills through writing procedure such as planning, editing, and revising. Tribble (1996) also argues process approach to writing has one crucial limitation which does not satisfy with the learners' needs with specific expectation. According to Zamel (1987), he criticizes the product approach which over-emphasizes the surface features of writing.

\section{The Application of the Genre Approach to Teaching Writing}

\section{The Benefit of the Genre Approach to Teaching Writing}

Torrance (1996) asserts that knowledge of genres facilitates the writing process. Hyland (2004) claims genre approach can refer to professional academic forms and writing texts, which stresses the importance of description and analysis. Harmer (2007) consolidates and develops his view by saying, "A genre approach is especially appropriate for students of English for Specific Purposes" (p. 327). In general, a writing task of a certain genre is helpful for students to produce written work. When the students are told to produce a specific text using the genre approach, the pattern of the genre will be memorized by the process of analyzing, practicing, imitating, and independently writing. Work by Cheng (2006) on writing instruction finds that students learn best from active, but guided learning, in which the teacher gives instructions to the students through the task. Moreover, the genre approach is not merely about mastering the framework of the text. The genre approach can extend students' utmost knowledge by contributing to students' mastering of various academic genres such as reports, essays, and application letters. Hammond (1992) lists some of them as examples: Personal letters are for telling someone private matters; an advertisement concerns description using comparative and superlative adjectives; a job application letter is from the angle of the employer; a newspaper editorial may involve commentary on contemporary politics.

Flowerdew (2000) also investigates the effectiveness of the genre approach to writing by claiming that genre approach exposes students to authentic materials. The genre approach presents samples to learners who have very little exposure to realistic written work, allowing them to have access to real materials. Bhatia (1993) argues business and scientific genres into self-access English for business and technology materials, which provides students with model of genres, such as promotion letter, job application. Furthermore, it can be used as a method to encourage and motivate the learners. Some students lack confidence and enthusiasm for writing. Harmer (2007) suggests genre approach provides the pattern for learners to follow; in addition, patterns and schemes help students to write with confidence. Teaching approaches that give students a model of a certain genre to emulate enable students to gain the accomplishment of mastering some specific knowledge. Therefore, genre approach can be regarded as an efficient way to motivate students in writing.

\section{Implementations of Genre Approaches in China and Suggestions}

Having discussed how genre facilitates writing in a second language, implementation and applying it to writing has been a central concern for English teachers. Dudley-Evans (1997) has advocated three writing stages in genre approach. Firstly, a sample of a specific genre is introduced to students and analyzed. Then students identify and exercise common language patterns; finally, they produce the generic product by themselves. These writing steps parallel product approaches closely. Badger and White (2000) propose that a 
genre approach should be considered as an extended part of a product approach. The similarity it shares with product approach is emphasized on linguistic aspect, while genre approach lays stress on the importance of the social context. Different types of genre have different requirements for special knowledge. However, since students may obtain different knowledge and perhaps begin to be interested in different subjects by studying different genres, one more stage should be added in the process of genre-based approach: discussing the background knowledge and generating ideas (QIN, 2000). The learning process should be modeling, analyzing the linguistic features of models, discussing the knowledge related to the topic, and producing the text independently. In addition, Cheng (2006) mentions the necessity of exploring learner dynamics in ESP genre-based writing classroom and developing theories of learning applicable to ESP genre-based writing instruction. Therefore, teachers should pay more attention to arouse students' interests on writing in the classroom for special purposes and also need to explore more useful theories from different angles so as to use for practise teaching.

Moreover, teachers also should emphasize on the utilization of genre to teaching writing which could guide the students to identify the writing purposes in writing classes guiding the students to identify the writing purposes in writing. As Meyers (2005) argues, "For genre analysts, the central aspect of the situation is purpose. Genres are also influenced by other features of the situation, such as the subject matter, the relationships between the writer and the audience, and the pattern of organization" (p. 5). According to Harmer (2007), the concept of genre depends highly on specific purposes for certain discourse communities.

As illustrated in the above analysis, due to the limitation of the genre approach which lacks an emphasis on writing process, Badger and White (2000) propose a new approach called the process-genre approach by adding the process to the genre approaches, which begins with models, and then comes the identification of the main linguistic features, discussion of the social context, and investigation of the suggested rhetorical patterns used in different genres. The language teacher should utilize the listening, speaking, and reading techniques in the writing class. The integration of the four skills benefits the students' language proficiency (Harmer, 2007). The process genre approach makes it feasible; to analyze and gather material refers to reading in prewriting activities and speaking and listening can be found in the process of instruction and discussion as well as giving or receiving feedback. Since students' generic product is still based on the models, the approach makes sure that the students could study the form, purpose, and the context of a specific genre, and write in the process of prewriting, first drafting, revising, and further revising and editing. Writing in this procedure allows students to realize the writing process as well as the different text types (Kay \& Dudley-Evans, 1998). Moreover, Swami (2008) suggests teachers should help students be clear about the organizational structure as well as the language usage, even improve students' self-confidence in writing.

\section{Conclusion}

In general, writing is a necessary but difficult skill for L2 students to master in China. The analysis above suggests that genre approach which is more than the emulation of the form is beneficial to writing. The learning process of the genre approach which helps learners follow a model which can be regarded as a writing process. In this way, the genre approach can develop students' writing proficiency. Besides, it works better when combined with the process approach. Even though the generic writing task is undertaken in the classroom, the 
genre approach, which is practical and meaningful, relates closely to the real life situation. To summarize, mastery of the generic writing skill will prepare the learners to writing in different genres in the future, especially for the students who are going to learn English for specific purpose such as Business English, Engineering or Scientific English. Although ESP courses in college are becoming popular in china nowadays, they still need to be further explored and developed concretely and comprehensively. As Cheng (2006) hopes the genre-based researchers will devote their research energy to conceptualizing learning in the ESP contexts and contribute to L2 learning and teaching.

\section{References}

Badger, R., \& White, G. (2000). A process genre approach to teaching writing. ELT Journal, 54(2), 153-160.

Bhatia, V. K. (1993). Analyzing genre: Language use in professional settings. London: Longman.

Cheng, A. (2006). Understanding learners and learning in ESP genre-based writing instruction. English for Specific Purposes, 25(1), 76-89

Dudley-Evans, T., \& St. John, M. J. (1998). Development in English for specific purposes: A multi-disciplinary approach. London: Cambridge University Press.

Flowerdew, L. (2000). Using a genre-based framework to teach organizational structures in an academic writing. ELT Journal, 54(4), 369-378

Hammond, J. (1992). The pedagogical relation between adult ESL and adult literacy. Canberra: Commonwealth of Australia.

Harmer, J. (2007). The practice of English language teaching. Harlow: Pearson Longman.

Hyland, K. (2008). Teaching and researching writing (2nd ed.). London: Pearson Education.

Hyon, S. (1996). Genre in three traditions: Implication for ESL. TESOL Quarterly, 30, 693-722.

Johns, A. M. (2002). Genre and ESL/EFL composition instruction. In B. Kroll (Ed.), Exploring the dynamics of second language writing. New York: Cambridge University Press.

Kay, H., \& Dudley-Evans, T. (1998). Genre: What teachers think. ELT Journal, 52(4), 308-314.

Meyers, A. (2005). Gateways to academic writing: Effective sentences, paragraphs, and essays. London: Pearson Education.

QIN, X. B. (2000). An analysis of genre-based teaching approach. Foreign Language Teaching and Research, 32(1), 44-46.

Swales, J. M. (1990). Genre analysis: English in academic and research settings. London: Cambridge University Press.

Swales, J., \& Feak, C. (1994). Academic writing for graduate students. Ann Arbor: University of Michigan Press.

Swami, A. J. (2008). Sensitizing ESL learners to genre. The Electronic Journal for English as a Second Language, 12(3).

Tribble, C. (1996). Writing. Oxford: Oxford University Press.

Zamel, V. (1987). Recent research on writing pedagogy. TESOL Quarterly, 21(4), 697-715. 